\title{
KEHARMONISAN KELUARGA DAN KENAKALAN REMAJA PADA SISWA KELAS 9 MTS NEGERI 2 PALEMBANG
}

\author{
Desy Oktaviani, Lukmawati \\ Fakultas Psikologi, UIN Raden Fatah Palembang \\ dheassi_winter@yahoo.com, lukmawati_uin@radenfatah.ac.id
}

\begin{abstract}
The goal of this research is for examine relationship between harmony family with delinquency teenagers. The sample of this research is IX class of the MTs negeri 2 palembang consist of 173 Students. The methods used data using the Statistical Programme for Social Science (SPSS) versi 20.00 for windows to test the relationship between harmony of family and delinquency teenagers. The result of Product Moment Correlation showed the number $r=-0,598$ with $\rho=0.000$ where $(\rho<0.01)$, it can be concluded that there is a negative relationship which is significant between harmony family and deliquency teenagers from IX class students of MTs Negeri 2 Palembang. The Negative association shows that the higher that harmony family the lower is delinquency teenagers vice verse lower is harmony family the increasingly high deliquency teenagers happened.
\end{abstract}

Keywords: Harmony Family, Deliquency Teengers

\begin{abstract}
ABSTRAK
Penelitian ini bertujuan untuk menguji hubungan antara keharmonisan keluarga dengan kenakalan remaja. Hipotesis yang diajukan dalam penelitian ini, ada hubungan antara keharmonisan keluarga dengan kenakalan remaja pada siswa kelas IX Mts negeri 2 Palembang. Sampel dalam penelitian ini adalah siswa-siswi kelas IX di MTs Negeri 2 palembang yang berjumlah 173 siswa. Metode analisis data yang digunakan menggunakan program Statistical Programme for Social Science (SPSS) versi 20.00 for windows untuk menguji hubungan antara keharmonisan keluarga dengan kenakalan remaja. Hasil korelasi product moment menunjukkan angka korelasi $r=-0.598$ dengan $\rho=0.000$ dimana $(\rho<0.01)$, maka dapat disimpulkan bahwa ada Hubungan Negatif Yang sangat Signifikan Antara Keharmonisan Keluarga Dengan Kenakalan Remaja Pada Siswa Kelas IX Di MTS Negeri 2 Palembang. Hal ini dapat diartikan bahwa semakin tinggi keharmonisan keluarga maka semakin rendah kenakalan remaja begitu juga sebaliknya semakin rendah keharmonisan keluarga maka semakin tinggi kenakalan remaja yang terjadi.
\end{abstract}

Kata Kunci: Keluarga, Kenakalan Remaja

\section{PENDAHULUAN}

Selama rentang kehidupan manusia banyak terjadi perubahan atau baik perubahan fisik maupun psikis yang dimulai sejak lahir sampai meninggal dunia. Semua fase perkembangan dan pertumbuhan manusia tersebut. Salah satu fase yang penting dan menjadi pusat perhatian adalah fase remaja. Dianggap penting karena kelak remaja inilah yang akan menjadi pemimpin dan pejuang penerus bangsa.

Masa remaja juga sering disebut sebagai periode peralihan dari masa anakanak menuju masa dewasa, hal ini disebabkan karena status individu tidaklah jelas dan terdapat keraguan akan peran yang harus dilakukan. Pada masa ini remaja bukan lagi bukan lagi seorang anak dan juga bukan orang 
dewasa. Kalau remaja berperilaku seperti anak-anak, ia akan diajari untuk betindak sesuai umurnya. Namun jika remaja berperilaku seperti orang dewasa ia akan dicap sebagai anak yang dewasa sebelum waktunya (Hurlock \& Elizabeth, 1980)

Pada masa ini akan timbul berbagai kemungkinan seseorang akan berkembang. Perkembangan yang meliputi aspek fisik dan psikis yang akan membawa atau menimbulkan dampak baik bagi remaja itu sendiri, orang tua dan orang-orang sekitarnya. Pada tahap remaja seorang anak mulai berusaha untuk mencari jati diri dan remaja yang sehat fisik maupun sehat mental, yaitu remaja yang mampu menyelesaikan tugastugas hidupnya dan mampu menghadapi tantangan-tantangan baik yang berasal dari dalam dirinya maupun dari luar dirinya. Perubahan-perubahan kepribadian disini sangat cepat dan menimbulkan banyak ketegangan. Pada masa transisi ini terjadi storm and stress yang ditandai dengan emosi yang bergolak serta mempengaruhi daya pikir dan perilakunya.

Selain itu masa remaja adalah masa yang paling tepat untuk mengembangkan keterampilan sehingga dalam usia yang relatif muda dapat menjadi yang kreatif dan dinamis. Semua ini tentu saja tidak dapat dicapai begitu saja akan tetapi melalui proses yang cukup panjang dan penuh dengan hambatan, tantangan, atau gangguan. Bila masa remaja didukung perlakuan yang tepat (moril) dan sarana prasarana (materil) yang baik, maka remaja akan tumbuh dan berkembang dengan baik (Hurlock \& Elizabeth, 1980).

Namun jika kebutuhan tersebut tidak terpenuhi tidak jarang beberapa remaja melakukan penyimpangan-penyimpangan yang melanggar norma, baik norma sosial, agama, maupun hukum. Istilah yang biasa digunakan untuk menyebutnya ialah kenakalan remaja atau Juvenile Delinquency.
Kenakalan remaja ialah perilaku jahat (dursila), atau kejahatan/ kenakalan anak-anak muda; merupakan gejala sakit (patologis) secara sosial pada anak-anak dan remaja yang disebabkan oleh suatu bentuk pengabaian sosial, sehingga mereka itu mengembangkan bentuk tingkah laku yang menyimpang (Kartono, 2014).

Selanjutnya menurut Sumiati (2009) kenakalan remaja adalah tingkah laku yang melampaui batas toleransi orang lain dan lingkungannya. Tindakan ini dapat merupakan perbuatan yang melanggar hak azasi menusia sampai melanggar hukum.

Berdasarkan definisi diatas, dapat simpulkan bahwa kenakalan remaja adalah suatu bentuk perilaku melanggar hukum baik hukum sosial, budaya, dan hukum yang dilakukan oleh anak remaja.

Jensen membagi kenakalan remaja menjadi empat bentuk, yaitu:

1 Kenakalan yang menimbulkan korban fisik pada orang lain: perkelahian, perkosaan, perampokan, pembunuhan, dan lain-lain.

2 Kenakalan yang menimbulkan korban materi: perusakan, pencurian, pencopetan, pemerasan, dan lain-lain.

3 Kenakalan sosial yang tidak menimbulkan korban dipihak orang lain: pelacuran, penyalahgunaan obat, melakukan hubungan seks sebelum menikah.

4 Kenakalan yang melawan status, misalnya mengingkari status anak sebagai pelajar dengan cara membolos, mengingkari status orang tua dengan cara minggat dari rumah atau membantah perintah mereka dan sebagainya (dalam Sarlito, 2012).

Sampai tahun 2011 ini kenakalan remaja terus mengalami peningkatan, hal ini dapat diketahui dengan melakukan pengamatan pada perilaku remaja di sekitar 
lingkungan kita, atau melalui media massa. Hampir setiap hari media cetak maupun elektronik memberitakan tentang perilaku kenakalan remaja.

Seperti kasus sejumlah siswa SMA di Surabaya yang menggunakan Narkoba (Liputan6, 2016). Lalu kasus lain terjadi di Bekasi, OV seorang pelajar tewas mengenaskan setelah terlibat, meninggal dengan satu luka tusuk yang mengenai jantung (Purba, 2017). Selanjutnya kasus yang terjadi di Kudus, sepasang remaja tertangkap kamera sedang memadu kasih di dalam salah satu angkutan kota (angkot) di kabupaten kudus, Jawa Tengah (Saputra, 2017).

Kasus tersebut hanyalah sebagian kecil dari sekian banyak kasus kenakalan remaja yang terjadi di Indonesia. Hal ini membuat semua orang terkhusus pada orang tua mencemaskan anaknya akan terseret ke dalam lingkaran kenakalan remaja.

Terkait hal di atas, permasalahan yang terjadi di lingkungan MTs Negeri 2 Palembang yang didapatkan oleh peneliti dari hasil observasi dan dokumentasi kepada pihak sekolah terdapat beberapa kenakalankenakalan ringan hingga berat yang pernah terjadi di lingkungan sekolah. Bentuk-bentuk pelanggaran ringan yang terjadi seperti bolos sekolah, ribut didalam kelas ketika kegiatan belajar mengajar berlangsung, jahil dengan teman yang terkadang menyebabkan pertengkaran, berbohong, berpakaian tidak sesuai dengan aturan yang ditetapkan sekolah, berbicara kasar, tidak sopan kepada guru, dll.

Sedangkan bentuk pelanggaran berat yang terjadi adalah ngelem, mencuri, kabur dari rumah, bergabung dengan kelompok anak punk, menyimpan video dan foto porno, berciuman dengan lawan jenis, merokok, dll. Beberapa contoh kasus-kasus pelanggaran berat yang pernah terjadi dan tercatat di buku kasus BK adalah kasus siswa yang berinisial MI yang ngelem diluar sekolah, lalu siswi berinisial L yang diadukan oleh bibi nya karena suka mencuri dan berbohong kepada bibinya. Kemudian kasus siswi berinisial A yang diketahui menyimpan foto dan video porno di telepon genggam.

Selanjutnya siswa berinsial FA yang kabur dari rumah dan bergaul dengan kelompok anak punk. Dan terakhir kasus siswa berinsial E yang dilapokan berciuman dengan 4 teman lelakinya di lingkungan sekolah. Kasus diatas adalah bentuk pelanggaran yang berat. Sedangkan untuk pelanggaran ringan ada kasus siswa berinisial AK yang diadukan temannya ke guru BK karena ia dikenal anak yang egois, jahil, sombong, cerewet, dan pelit., lalu siswa inisial MT ia dilaporkan oleh guru-guru karena suka ribut dikelas dan suka mengganggu temannya. Dan yang terakhir kasus siswa berinisial B, ia diadukan temantemannya karena suka bersikap kasar.

Diperkuat dengan hasil wawancara peneliti kepada guru BK MTS Negeri 2 Palembang. Menurut penuturan Guru BK tersebut memang terjadi beberapa kenakalankenakalan yang dilakukan oleh siswa, yang paling sering terjadi adalah pertengkaran antar siswa, ribut pada saat pelajaran berlangsung, jahil kepada teman, lalu jarang masuk sekolah tetapi tidak banyak yang melakukannya.

Kemudian pelanggaran kedisplinan yang sering terjadi adalah seragam yang tidak rapi dengan atibut yang tidak lengkap, lalu bersikap tidak sopan, yang terakhir berbicara kotor dan kasar, namun langsung ditegur oleh gurunya agar tidak menjadi kebiasaan dan terus dilakukan. Untuk bentuk pelanggaran yang berat seperti mencuri, ngelem, kabur dari rumah, merokok,dan lain-lain berdasarkan dari hasil wawancara peneliti kepada pihak guru BK memang tidak terlalu sering terjadi.

Melihat fenomena yang terjadi di sekolah tersebut membuat peneliti tertarik untuk mengetahui apa yang menyebabkan hal 
tersebut bisa terjadi. MTs Negeri 2 Palembang adalah sekolah menengah pertama yang berbasis Islam sehingga pengajaran disekolah pastilah menekankan pada aspek akhlak dan bagaimana berperilaku yang baik dan sesuai dengan ajaran agama Islam.

Jika dilihat secara umum banyak faktor yang menyebabkan kenakalan remaja. Faktor keluarga, lingkungan, dan sekolah dapat mempengaruhinya. Jika dilihat lebih jauh lingkungan sosial yang berinterksi pertama kali dengan anak adalah keluarganya. Keluarga yang terdiri dari ayah, ibu, dan saudara. Kondisi yang terjadi didalam keluarga dapat mempengaruhi apakah seorang anak akan tumbuh dengan baik atau tidak. Menurut Ahmadi (2009) Keluarga adalah unit satuan masyarakat yang terkecil sekaligus merupakan suatu kelompok kecil dalam masyarakat.

Kartono (2014) menyatakan secara umum dapat dinyatakan anak delinkuen (nakal) pada umumya datang dari rumah tangga dengan relasi manusiawi penuh konflik dan percekcokan, yang disharmonis atau tidak harmonis. Berdasarkan dari pendapat di atas, maka dapat diketahui bahwa salah satu faktor kenakalan remaja adalah keharmonisan keluarga.

Menurut Setiono (2011) keharmonisan keluarga adalah keadaan dimana interaksi antara anggota keluarga tidak terhambat, kebutuhan anggota keluarga terpenuhi. Di dalam Islam konsep keluarga harmonis sudah dimuat oleh Allah SWT dalam QS. ar-Rum (30): 21.

Berdasarkan ayat di atas bisa dipahami bahwa kehidupan rumah tangga yang harmonis menurut Islam, yaitu: Sakinah (assakinah), Mawadah (al-mawaddah), dan Rahmah, yaitu rasa kasih dan sayang sehingga tercipta ketentraman di dalam keluarga. Ketidak harmonisan keluarga dan tidak sesuainya pola asuh yang diterapkan oleh orang tua berakibat anak yang menjadi korban. Anak cenderung mengalami konflikkonflik internal, pemikiran kritis, perasaan mudah tersinggung, cita-cita dan kemauan yang tinggi sukar dikerjakansehingga menjadi frustasi, bahkan bias mengalami pergaulan yang tidak sehat. Ketidakharmonisan keluarga dapat ditandai dengan tidak berfungsinya orang tua sebagai figur tauladan bagi anak. Selain itu suasana keluarga yang menimbulkan rasa tidak aman dan tidak menyenangkan serta hubungan keluarga yang kurang baik dapat menimbulkan bahaya psikologis bagi setiap usia terutama pada masa remaja.

Orang tua dari remaja nakal cenderung memiliki aspirasi yang minim mengenai anakanaknya, menghindari keterlibatan keluarga dan kurangnya bimbingan orang tua terhadap remaja, sebaliknya, suasana keluarga yang menimbulkan rasa aman dan menyenangkan akan menumbuhkan kepribadian yang wajar dan begitu pula sebaliknya.

$\begin{array}{ccr}\begin{array}{c}\text { Sehingga } \\ \text { keharmonisan }\end{array} & \begin{array}{c}\text { dapat } \\ \text { keluarga }\end{array} & \begin{array}{r}\text { diartikan } \\ \text { adalah }\end{array}\end{array}$
keluargadimana anggota didalamnya bisa berhubungansecara serasi dan seimbang, saling memuaskankebutuhan anggota lainnya serta memperoleh pemuasan atas segala kebutuhannya.

Aspek-aspek keluarga harmonis menurut Hawari (2004) yaitu, menciptakan kehidupan beragama dalam keluarga, mempunyai waktu bersama keluarga, mempunyai komunikasi yang baik antar anggota keluarga, saling menghargai antar sesama anggota keluarga, kualitas dan kuantitas konflik yang minim, adanya hubungan atau ikatan yang erat antar anggota keluarga.

Banyak penelitian yang dilakukan oleh para ahli menemukan bahwa remaja yang berasal dari keluarga yang penuh perhatian, hangat, dan harmonis mempunyai kemampuan dalam menyesuaikan diri dan 
sosialisasi yang baik dengan lingkungan sekitarnya.

Menurut Hawari (2004) salah satu faktor penyebab timbulnya kenakalan remaja adalah tidak berfungsinya orangtua sebagai figur tauladan bagi anak. Selain itu, suasana keluarga yang menimbulkan rasa tidak aman dan tidak menyenangkan serta hubungan keluarga yang kurang baik dapat menimbulkan bahaya bagi setiap usia terutama pada masa remaja.

Penelitian lainnya oleh Ingram, Patchin, Huebner, Mc (2015) Cluskey, dan Bynum menyatakan bahwa variabel-variabel yang berasal dari keluarga secara tidak langsung berhubungan dengan perilaku kenakalan remaja serius. Penelitian dari Muniriyanto dan Suharnan (2014) didapatkan hasil bahwa ada hubungan yang signifikan antara keharmonisan keluarga dengan kenakalan remaja.

Jadi dari keluargalah semua itu berasal, apabila anak remaja dibesarkan dari keluarga yang utuh/tidak utuh (broken home) maka perkembangan anaknya akan mengarah kearah yang baik atau sebaliknya, Dalam situasi saat ini, anak-anak belajar untuk menghargai diri mereka sendiri dan orang lain, termasuk mengontrol tingkah laku mereka, karena adanya perubahan struktur, fungsi, dan sikap, maka orang tua tidak selalu dapat memenuhi kebutuhan anak. Pendapat yang lain juga menyebutkan Remaja yang hubungan keluarganya kurang baik juga dapat mengembangkan hubungan yang tidak menyenangkan dengan orang-orang di luar rumah. Berdasarkan uraian maka peneliti tertarik untuk meneliti hubungan antara keharmonisan keluarga dengan kenakalan remaja pada siswa kelas 9 MTs Negeri 2 palembang.

\section{METODE PENELITIAN}

Penelitian ini menggunakan jenis penelitian kuantitatif korelasional. Terdapat dua variabel yang diteliti dalam penelitian ini, yaitu kerharmonisan keluarga dan kenakalan remaja. Dalam penelitian ini kehamonisan keluarga adalah keadaan interaksi antara anggota keluarga tidak terhambat, kebutuhan anggota keluarga terpenuhi; dan khusus dari sudut pandang psikologi perkembangan, perkembangan kepribadian anggota keluarga optimal, mengingat keluarga adalah lingkungan pertama dan utama bagi anak untuk bekembang. Kenakalan remaja dalam penelitian ini didefinisikan sebagai perilaku jahat (dursila), atau kejahatan/kenakalan anak-anak muda; merupakan gejala sakit (patologis) secara sosial pada anak-anak dan remaja yang disebabkan oleh suatu bentuk pengabaian sosial, sehingga mereka itu mengembangkan bentuk tingkah laku yang menyimpang.

Populasi dalam penelitian ini berjumlah 305 siswa yaitu, seluruh siswa kelas 9 Mts N 2 Palembang, dimana terdapat 10 kelas. Karateristik populasi yang digunakan di dalam penelitian ini adalah:

1. Seluruh siswa-siswi kelas 9 MTs Negeri 2 Palembang.

2. Individu yang beragama islam.

3. Individu Laki-laki dan perempuan, berusia 13 sampai 15 tahun.

4. Individu yang bersedia menjadi responden penelitian.

Sampel diambil dengan menggunakan probability sampling dengan teknik simple random sampling. Metode pengumpul data yang digunakan dalam penelitian ini berbentuk skala dengan model skala likert, variabel terdiri dari 60 item pernyataan yang terbagi dalam bentuk pernyataan favorable dan unfavorable. Untuk mengukur keharmonisan keluarga peneliti membuat instrumen alat ukur sendiri berdasarkan aspek-aspek keharmonisan keluarga menurut Dadang Hawari dan skala kenakalan remaja menggunakan bentuk-bentuk kenakalan remaja menurut Jensen. 
Dalam penelitian ini uji validitas yang digunakan Corrected Item Total Correlation. Menurut Azwar (2017) kriteria penentuan item skala itu valid, jika nilai $r_{x} \geq 0,30$. Jika nilai $r_{x} \leq 0,30$, maka item skala tersebut dinyatakan gugur (tidak valid).

Sedangkan uji reliabilitas dengan menggunakan teknik koefisien alpha cronbach, yakni guna melihat hubungan antara dua variable. Reliabilitas dinyatakan oleh koefisien reliabilitas yang angkanya berada rentang dari 0 sampai 1,00. Semakin tinggi koefisien reabilitas mendekati angka 1,00 berarti rendah reliabilitasnya. Sedangkan metode analisis data dalam penelitian ini, dilakukan dalam dua tahap uji prasyaratan dan uji hipotesis. Uji prasayarat meliputi: (1) Uji normalitas, dan (2) Uji linieritas.

Uji normalitas yang digunakan dalam penelitian ini adalah One Sample Kolmogorov Smirnov $Z$ (KS-Z). Dengan ketentuan data dinyatakan berdistribusi normal jika nilai signifikansi lebih besar dari 0,05. Lalu uji linieritas dengan menggunakan curva estimation.Data dinyatakan linier jika nilai signifikansi lebih kecil dari 0,05 (Alhamdu, 2016). Sementara uji hipotesis yang digunakan dalam penelitian ini menggunakan analisis pearson product moment. Semua analisis didalam penelitian ini menggunakan bantuan program Statistical Programme for Social Science (SPSS) versi 20.00 for windows.

\section{HASIL DAN PEMBAHASAN}

Penelitian ini menggunakan analisis pearson product moment yang dilakukan untuk mengetahui apakah ada hubungan antara variabel keharmonisan keluarga dengan kenakalan remaja pada siswa kelas 9 MTs Negeri 2 Palembang.

Berdasarkan hasil kategorisasi diketahui bahwa sebagian besar siswa MTs Negeri 2 Palembang memiliki keharmonisan keluarga dalam kategori sedang, yaitu sebanyak 125 orang siswa atau sebesar 72,4\% sementara sisanya berada dalam kategori tinggi dan rendah. Untuk kategorisasi tinggi sebanyak 26 orang siswa atau sebanyak $15,2 \%$ dan untuk kategorisasi rendah sebanyak 22 orang siswayaitu13\%. Begitupun hasil kategorisasi kenakalan remaja diketahui bahwa sebagian besar siswa MTs Negeri 2 Palembang memiliki perilaku kenakalan remaja dalam kategori sedang, yaitu sebanyak 124 orang siswa atau sebesar 71,6\% sementara sisanya berada dalam kategorisasi tinggi dan rendah. Untuk kategorisasi tinggi sebanyak 27 orang siswa atau sebanyak $16 \%$ dan untuk kategorisasi rendah sebanyak 22 orang siswa atau sebanyak $12,7 \%$.

Selanjutnya, untuk uji normalitas diperoleh sebagai berikut:

1 Hasil uji normalitas terhadap variabel keharmonisan keluarga memiliki nilai signifikan sebesar 0.099. Berdasarkan data tersebut maka dapat dikatakan bahwa $\rho=0.099>0.05$, sehingga dapat dinyatakan bahwa data variabel keharmonisan keluarga berdistribusi normal.

2 Hasil uji normalitas terhadap variabel kenakalan remaja memiliki nilai signifikan sebesar 0.127. Berdasarkan data tersebut maka dapat dikatakan bahwa $\rho=0.127>0.05$, sehingga dapat dinyatakan bahwa data variabel kenakalan remaja berdistribusi normal.

Sementara uji linieritas, nilai signifikan yang diperoleh adalah sebesar 0.000 dan $\mathrm{R}$ square sebesar 0.357 . Hal ini berarti bahwa $\rho<0.05$ dan dapat dikatakan antara variabel keharmonisan keluarga dengan kenakalan remaja berhubungan secara linier.

Terakhir hasil dari uji hipotesis menunjukkan bahwa besarnya koefisien korelasi antara variabel keharmonisan keluarga dengan variabel kenakalan remaja - 
.598 dengan signifikansi hubungan kedua variabel sebesar 0.000 dimana $\rho<0.01$, maka hal ini menunjukkan bahwa keharmonisan keluarga memiliki hubungan negatif yang sangat signifikan dengan Kenakalan remaja pada siswa-siswi Kelas IX MTs Negeri 2 Palembang. Hal ini dapat diartikan bahwa semakin tinggi keharmonisan keluarga maka semakin rendah Kenakalan remaja begitu juga sebaliknya semakin rendah keharmonisan keluarga maka semakin tinggi Kenakalan remaja.Dengan demikian hipotesis penelitian yang diajukan dapat diterima.

Hasil di atas sejalan dengan pendapat Hawari (2004) salah satu faktor penyebab timbulnya kenakalan remaja adalah tidak berfungsinya orang tua sebagai figur teladan bagi anak. Selain itu suasana keluarga yang menimbulkan rasa tidak aman dan tidak menyenangkan serta hubungan keluarga yang kurang baik dapat menimbulkan bahaya bagi setiap usia terutama pada masa remaja.

$\begin{array}{crr}\text { Lebih } & \text { lanjut } \quad \text { Yusuf } & \text { (2012) } \\ \text { mengemukakan } & \text { faktor-faktor } & \text { yang }\end{array}$ mempengaruhi perilaku menyimpang pada remaja adalah: Kelalaian orang tua dalam mendidik anak (memberikan ajaran dan bimbingan tentang nilai-nilai agama), perselisihan atau Konflik orang tua (antaranggota keluarga), perceraian orang tua, sikap perlakuan orang tua yang buruk terhadap anak, kehidupan ekonomi keluarga yang morat-marit (miskin/fakir), penjualan alat-alat kontrasepsi yang kurang terkontrol, Hidup menganggur, kurang dapat memanfaatkan waktu luang, diperjual belikannya minuman keras/ obat-obatan terlarang secara bebas, Kehidupan moralitas masyarakat yang bobrok, peredaran film-film atau bacaan-bacaan porno, dan pergaulan negatif (Samsu, 2012).

Selanjutnya, berdasarkan perhitungan kategorisasi skor variabel keharmonisan keluarga, dari 173 sampel penelitian didapat 26 subjek dengan persentase $15,2 \%$ berada dalam taraf kategori tinggi. 125 subjek dengan persentase $72,4 \%$ berada dalam taraf kategori sedang. Sisanya 22 subjek dengan persentase $13 \%$ berada dalam taraf kategori rendah. Berdasarkan hasil perhitungan dapat disimpulkan bahwa kategorisasi skor variabel keharmonisan keluarga pada siswa-siswi kelas IX di MTs Negeri 2 Palembang berada pada taraf sedang.

Keharmonisan keluarga adalah keadaan interaksi antara anggota keluarga tidak terhambat, kebutuhan anggota keluarga terpenuhi; dan khusus dari sudut pandang psikologi perkembangan, perkembangan kepribadian anggota keluarga optimal, mengingat keluarga adalah lingkungan pertama dan utama bagi anak untuk bekembang (Setiono, 2011).

Keharmonisan keluarga itu akan terwujud apabila masing-masing unsur dalam keluarga itu dapat berfungsi dan berperan sebagimana mestinya dan tetap berpegang teguh pada nilai- nilai agama kita, maka interaksi sosial yang harmonis antar unsur dalam keluarga itu akan dapat diciptakan.

Ketidakharmonisan keluarga dan tidaksesuainya pola asuh yang diterapkan oleh orang tua berakibat anak yang menjadi korban. Anak,cenderung mengalami konflikkonflik internal, pemikiran kritis, perasaan mudah tersinggung,cita-cita dan kemauan yang tinggi sukar dikerjakan sehingga menjadi frustasi, bahkan bisa mengalami pergaulan yang tidak sehat. Ketidak harmonisan keluarga dapat ditandai dengan tidak berfungsinya orang tua sebagai figur tauladan bagi anak. Selain itu suasana keluarga yang menimbulkan rasa tidak aman dan tidak menyenangkan serta hubungan keluarga yang kurang baik dapat menimbulkan bahaya psikologis bagi setiap usia terutama pada masa remaja. Orang tua dari remaja nakal cenderung memiliki aspirasi yang minim mengenai anak-anaknya, menghindari keterlibatan keluarga dan 
kurangnya bimbingan orang tua terhadap remaja, sebaliknya, suasana keluarga yang menimbulkan rasa aman dan menyenangkan akan menumbuhkan kepribadian yang wajar dan begitu pula sebaliknya.

Berdasarkan uraian di atas, maka dapat dikatakan bahwa anak yang tumbuh dan berkembang di lingkungan keluarga harmonisan yang tinggi akan membuat anak mampu untuk melewati setiap konflik yang diamalami dengan bantuan dan dukungan dari keluarga, sehingga anak akan memiliki rasa aman dan membuat anak tidak melakukan perbuatan yang melanggar norma. Sedangkan anak yang tumbuh di lingkungan keluarga yang tidak harmonisan akan menyebabkan anak melakukan tindakan yang melanggar normal karena ia memandang dunia sebagai tempat yang tidak aman.

\section{SIMPULAN}

Berdasarkan hasil analisis data penelitian menggunakan uji korelasi analisis product moment menunjukkan angka korelasi $\mathrm{r}=-0.598 ; \rho=0.000$ atau $\rho<0.01$, dapat disimpulkan bahwa ada hubungan negatif yang sangat signifikan antara Keharmonisan Keluarga dengan Kenakalan Remaja pada Siswa kelas IX di MTs Negeri 2 Palembang. Hal ini dapat diartikan bahwa semakin tinggi keharmonisan keluarga maka semakin rendah kenakalan remaja begitu juga sebaliknya semakin rendah keharmonisan keluarga maka semakin tinggi kenakalan remaja yang terjadi.Dengan demikian hipotesis yang diajukan sebelumnya diterima.

\section{DAFTAR PUSTAKA}

Ahmadi, A. (2009). Ilmu Sosial Dasar. Jakarta: PT.Rineka Cipta.

Alhamdu. (2016). Analisis Statistik Dengan Program SPSS. Palembang: NoerFikri Offset.
Azwar, S. (2017). Penyusunan Skala Psikologi. Yogyakarta: Pustaka Pelajar.

Hawari, D. (2004). Al-Qur'an: Ilmu Kedokteran Jiwa dan Kesehatan Jiwa. Yogyakarta: Dana Bhakti Prima Yasa.

Hurlock, \& Elizabeth, B. (1980). Psikologi Perkembangan: Suatu Pendekatan Sepanjang Rentang Kehidupan (Edisi Kelima). Jakarta: Erlangga.

Ingram, J. R., Patchin, J. W., Huebener, B. M., McCluskey, J. D., \& Bynum, T. S. (2015). (2015).Parents, Friends, and Serious Delinquency An Examination of Direct and Indirect Effects Among At-Risk Early Adolescents. Criminal Justice Review , 32.

Kartono, K. (2014). Patologi Sosial 2 kenakalan Remaja. Jakarta: Raja Grafindo Persada.

Liputan6. (2016, Oktober 7). VIDEO: 6 Pelajar Ini Dimarahi Risma karena Memakai Narkoba. Retrieved April 16, 2017, from Liputan 6: https://www.liputan6.com/news/read/2 620046/video-6-pelajar-ini-dimarahirisma-karena-memakai-narkoba

Muniriyanto, \& Suharnan. (2014). Keharmonisan Keluarga, Konsep Diri Dan Kenakalan Remaja. Psikologi Indonesia Persona , 3.

Purba, F. (2017, Maret 11). Tawuran Antarpelajar, Satu Siswa SMP di Bekasi Tewas. Retrieved April 16, 2017, from Liputan 6: https://www.liputan6.com/news/read/2 882958/tawuran-antarpelajar-satusiswa-smp-di-bekasi-tewas

S. L. (2012). Psikologi Perkembangan Anak dan Remaja. Bandung: PT. Remaja Rosdakarya.

Saputra, G. (2017, April 11). Sepasang Remaja di Kudus Asyik Pacaran di Angkot Selasa. Retrieved April 16, 2017, from Semarang Pos: 
60| Psikis : Jurnal Psikologi Islami Vol. 4 No. 1 Juni 2018

http://m.semarangpos.com/2017/04/11

/sepasang-remaja-di-kudus-asyik-

pacaran-di-angkot-808817

Sarlito, S. W. (2012). Psikologi Remaja. Jakarta: Rajawali Pers.

Setiono, K. (2011). Psikologi Keluarga, Bandung. Bandung: PT. Alumni.

Sumiati, D. (2009). Kesehatan Jiwa Remaja dan Konseling. Jakarta: Trans Indo Media. 